\title{
Antimicrobial and antifungal activity of pumpkin (Cucurbita pepo) leaves extracted by four organic solvents and water
}

\author{
H. Mohammed ${ }^{1}$, R.S. Najem ${ }^{2}$ and S.S.A. Altekrity ${ }^{2}$ \\ ${ }^{1}$ Department of Microbiology, ${ }^{2}$ Department of Physiology, Biochemistry and Pharmacology, College of Veterinary \\ Medicine, Tikrit University, Tikrit, Iraq
}

(Received October 26, 2017; Accepted November 24, 2017)

\begin{abstract}
Pumpkin is a rich source of vitamin A, being high in beta-carotene, a precursor to vitamin A. It provides substantial fiber, niacin, and lutein (important antioxidant). Pumpkin seeds have many health benefits, some of which include a good source of protein, zinc, and other vitamins, and are even said to lower cholesterol, Pumpkin plant was mentioned in the holy Quran as protector to protect the prophet Yonah, peace upon him after his expulsion from the whale. The present work was design to elucidate and evaluate different organic solvents i.e. (Distilled water, Ethanol, Hexane, and Petroleum ether) extracts of pumpkin leaves against some of the pathogenic bacteria and fungi. The results showed pumpkin leaves extracts were able to inhibit bacterial (Escherichia coli, Klebsiella pneumonia, Staphylococcus aureus, Proteus mirabilis and Pseudomonas aeruginosa) and fungal (Aspergillus fumigatus, Aspergillus niger, and Candida albicans) growth, comparable with the known antibiotic Ciprofloxacin and the antifungal drug Kenazole. There were no significant differences among different solvents in their ability to produce anti- microbial activity except petroleum ether. Petroleum ether extracts did not show any bacterial growth retardation while it showed anti -fungal inhibition in higher concentrations for Aspergillus fumigates and Aspergillus niger, while Candida albicans seem to be resistant to the petroleum ether extract of pumpkin leaves.
\end{abstract}

Keywords: Pumpkin, Cucurbita Pepo Leaves, Antimicrobial, Antifungal, Organic Solvents Available online at http://www.vetmedmosul.org/ijvs

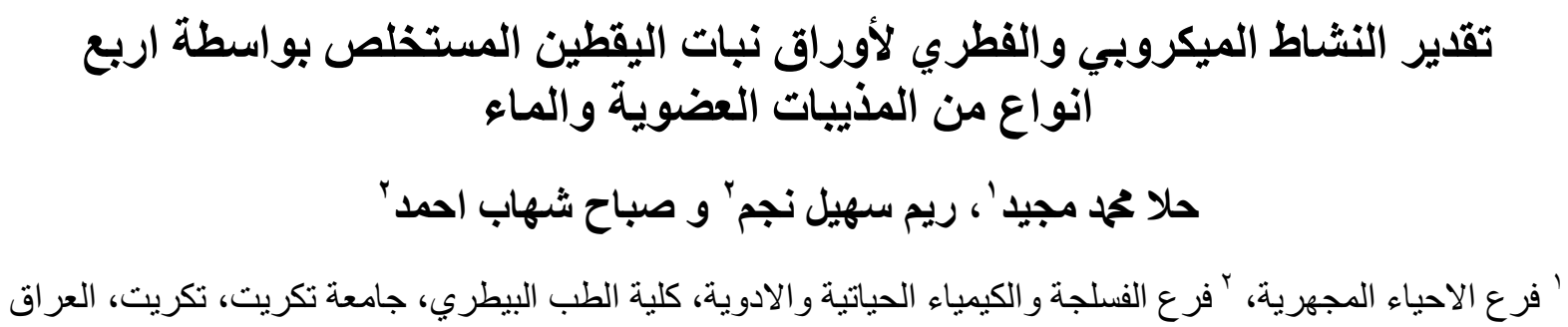

يعتبر اليقطين مصدر غني بفيتامين A من نوع بيتا كاروتين ويوفر نسبة عالية من الالياف المهمة المضادة للاكسدة هي النياسين

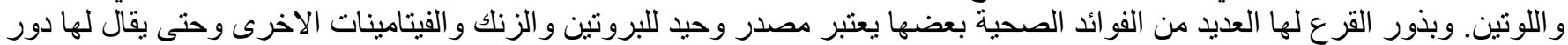

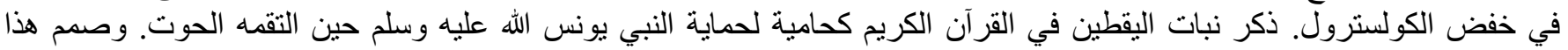

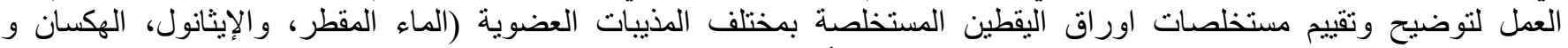

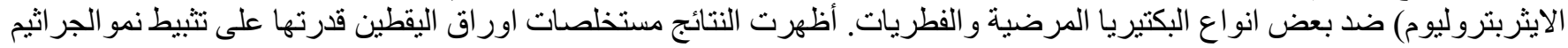
Escherichia coli, Klebsiella pneumonia Staphylococcus aureus, Portus mirabilis and Pseudomonas aeruginosa

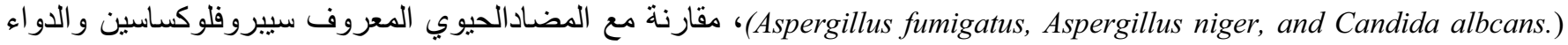

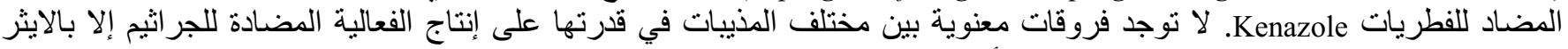

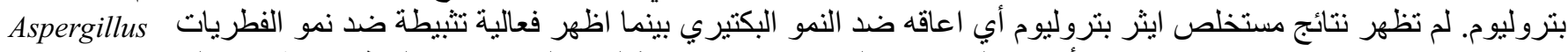

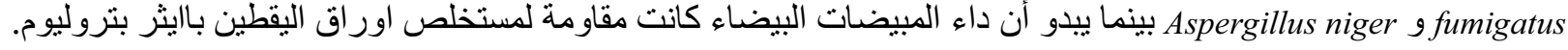




\section{Introduction}

Plants and their products is an issue among others were mentioned in the holy Quran were proved to have some kind of medicinal properties, such as Olive, Date, Fig, Manna of Hedysarum, Onion, Garlic and pumpkin and others (1).

A pumpkin is a gourd-like squash of the genus Cucurbita and the family Cucurbitaceae. It commonly refers to cultivars of any one of the species Cucurbita Pepo, Cucurbita mixta, Cucurbita maxima, and Cucurbita moschata. Pumpkins are widely grown for commercial use in food and recreation. It is an important family consisting 125 genera and 960 species (2).

Researches for screening new antimicrobial agent from plants and other microorganisms like fungi were increased to overcome resistant built by pathogenic bacteria to many pharmaceutical drugs (3). Recent researches stated that $74 \%$ of 119 plant-derived pharmaceutical compounds or biotechnology medicines were used in modern medicine. (4-6) have proved its effectiveness in fighting pathogenic bacteria and fungi this is due to the fact that this plant contain active compounds such as essential oil and terpenoids, amongst which can be cited xanthones, benzophenones, coumarins and flavonoids. Other researchers concluded from previous researches and traditional and modern folk applications, that coverage of potato tubers by fresh leaves of pumpkin actually reduce the attack of the potato tuber moth because of its repellent, oviposition deterrent, the insecticidal effect on larvae and adults of Potato tubers moth, that idiosyncrasy, modern folk healers avocado pumpkin seeds to rid the intestinal worms and to expel parasites (4) so the pumpkin oil insecticidal and repellency effect may be successfully used beside fresh leaves to give the best results. Methanol extracts from the fruity body of pumpkin (Cucurbita pepo) showed antibacterial activity against Escherichia coli, Staphylococcus aureus and Klebsiella pneumonia $(7,8)$. The present work was design to elucidate and evaluate different organic solvent and water extracts of pumpkin leaves against some of the pathogenic bacteria and fungi.

\section{Materials and methods}

\section{Plant and extraction}

Pumpkin leaves were collected from pumpkin local farm in Albuajeel village - Tikrit -Iraq during September and October 2015. The leaves were rinsed with distilled water to remove the dust. Then rudimentary dried with clean cotton clothes, then placed on the dry cotton sheath, in the dark place for complete dryness at a temperature range between $22-25^{\circ} \mathrm{C}$. The leaves were overturned every day. After dryness, the leaves were crushed and pulverized to pass $0.02 \mathrm{~mm}$ sieve.

Fifty gm. of the powdered leaves were extracted with $250 \mathrm{ml}$ of different solvents (including: Distilled water, Ethanol, Hexane, and Petroleum ether), for 48 hours under $45^{\circ} \mathrm{C}$. After complete dryness, the extracts were quantitatively collected and the yields of each extraction were calculated as a percentage of the primary weight of the dry leaves.

The dry extracts were dissolved in dimethyl sulphoxide (DMSO)-(Aldrich Merck, Germany) to insure complete solubilization. Three different concentrations of each extract $3.8 \%, 3.2 \%, 2.4 \%$, and $2.2 \%$ were prepared using DMSO as a solvent $(9,10)$. Antibacterial and antifungal activities, were detected following the methods described by (11).

\section{Microorganisms}

The bacterial species were Escherichia coli, Klebsiella pneumonia Staphylococcus aureus, Proteus mirabilis and Pseudomonas aeruginosa and the fungal species Aspergillus fumigatus, Aspergillus niger, and Candida albicans. were obtained as pure bacterial culture on MacConkey agar slant and the pure fungal culture on Sabouraud dextrose agar Slants were obtained from Microbiology department - College of Veterinary Medicine- Tikrit University. Identification of the microorganisms was performed by conventional biochemical methods system (12). The bacteria and the fungi isolates from agar slants were re-culture on nutrient broth for 24 hours. The nutrient broth cultures were adjusted to be compared with MC Farland standard to have $1.5 \times 10^{8}$ cells.

\section{Antibiotics and antifungal drugs}

The antibiotics used in this study was a broad spectrum antibiotic (Ciprofloxacin), obtained from State Company for the drug industry and medical appliance, Sammara Iraq. Antifungal, Kenazole, $200 \mathrm{mg}$. its active ingredient Ketoconazole; Domina pharmaceuticals - Syria) was purchased from local pharmacy. The antibiotic and antifungal were used as positive control, treated with the same procedure used for preparation different concentrations of pumpkin leave extracts.

\section{Antibacterial and antifungal assay}

Nutrient agar plates were prepared and the anti-bacterial and anti-fungal activity of different extracts and the antibiotics were performed using modified agar diffusion method according to (13). From fresh nutrient broth culture, $0.1 \mathrm{ml}$ of each species of bacteria and fungi was streaked evenly on nutrient agar using a sterile L-shape glass rod, and let to stand in the incubator for one hour. Afterward, 
three wells were done using sterile cork borer of diameter $5 \mathrm{~mm}$ on the agar plate.

The wells were filled with $0.1 \mathrm{ml}$ of extract samples from each concentration used and the antibiotics or the antifungal drug. The inoculated agar plates were left in refrigerator for one hour for proper diffusion then plates were incubated, at $37^{\circ} \mathrm{C}$ for 24 hours, for the bacteria and 36 hours for the fungi. The diameters of the zones of inhibition around each well were measured by caliper. Each test was carried out in three replicate and the mean diameters and standard deviation were recorded.

\section{Statistical analysis}

The experimental results were expressed by the mean \pm standard deviation of the diameter of the inhibitory zones The data were analyzed using one-way analysis of variance (ANOVA) using an online program (14).

\section{Results}

The yields of different solvents extractions were, 3.8\%, $3.2 \%, 2.4 \%$, and $2.2 \%$, for water, ethanol, hexane, and petroleum ether respectively.

Watery extract of pumpkin leaves gave important and considerable antibacterial activities against $E$. coli, $K$. pneumonia, Proteus marbilis, and Staphylococcus aureus and in some instance were comparable or greater than the antibiotic (Ciprofloxacin). The suppression of the bacterial growth was in ascending form with the increase in the concentration of extracts. The inhibitory zones for E. coli as an example were $25.00 \pm 1.63,26.33 \pm 0.47$ and $31.00 \pm 2.94$ $\mathrm{mm}$ in the watery extract concentrations $10 \%, 15 \%$, and
$25 \%$ respectively, while the inhibitory zones of the same bacteria due to the antibiotic (Ciprofloxacin) concentrations $10 \%, 15 \%$, and $25 \%$ were $17.67 \pm 2.52,21.67 \pm 1.53$, and $29.33 \pm 1.55 \mathrm{~mm}$ respectively. The results revels no significant differences between the inhibitory zones of different species of the bacteria under this study with pumpkin extracts or antibiotics. table 1 , showed the inhibitory zones diameters of the bacteria under this study.

Anti-fungal activity of the pumpkin leaves extract showed the same trends in their activity against bacteria against Aspergillus fumigatus, Aspergillus niger, and Candida albicans table 2, and figure 2.

\section{Organic solvents extract}

Organic solvents extract, i.e. Hexane, and Ethanol, extracts show considerable and important antibacterial and anti-fungal activities as expressed by the inhibitory zones of microorganism growth as shown in tables (3-6) and figures (3 -6). Differences among different solvents in their extracts activities were presented in figures (7). There were no significant differences among different solvents in their ability to produce anti- microbial activity except petroleum ether.

Petroleum ether extracts did not show any bacterial growth retardation while it showed anti-fungal inhibition in higher concentrations for Aspergillus fumigates and Aspergillus niger, while Candida albicans seem to be resistant to the petroleum ether extract of pumpkin leaves. $10 \%$ extract concentration shows no activity against Candida albicans.

Table 1: The diameter of the inhibitory zones $(\mathrm{mm})$ of the bacterial growth due to watery pumpkin leaves extracts and antibiotic (Ciprofloxacin) in different concentration

\begin{tabular}{|c|c|c|c|c|c|c|c|}
\hline \multirow[t]{2}{*}{ Types of bacteria } & \multicolumn{7}{|c|}{ Watery Pumpkin leaves extracts (P.L.E.) and antibiotic (AB) concentrations } \\
\hline & & E. $10 \%$ & P.L.E. $15 \%$ & P.L.E. $25 \%$ & AB. $10 \%$ & AB. $15 \%$ & AB. $25 \%$ \\
\hline E.coli & & $\pm 1.63^{*}$ & $26.33 \pm 0.47$ & $31.00 \pm 2.94$ & $17.67 \pm 2.52$ & $21.67 \pm 1.53$ & $29.33 \pm 1.55$ \\
\hline K. pneumonia & & $0 \pm 3.56$ & $26.00 \pm 2.94$ & $27.00 \pm 0.82$ & $0.00 \pm 0.0$ & $16.67 \pm 2.31$ & $28.67 \pm 2.31$ \\
\hline Pro. marbilis. & & $3.33 \pm$ & $26.00 \pm 1.67$ & $29.00 \pm 1.63$ & $12.67 \pm 2.82$ & $16.67 \pm 1.53$ & $24.00 \pm 1.00$ \\
\hline Stap.aureus & & $7 \pm 0.94$ & $22.67 \pm 1.70$ & $28.00 \pm 0.82$ & $18.00 \pm 1.33$ & $20.67 \pm 1.55$ & $27.00 \pm 1.00$ \\
\hline P. aeruginosa & & 0.00 & 0.00 & 0.00 & $12,67 \pm$ & $16.00 \pm$ & $19.00 \pm$ \\
\hline $\mathrm{N}$ & & 5 & 5 & 5 & 5 & 5 & 5 \\
\hline$X$ & & 3.600 & 20.200 & 23.000 & 12.068 & 18.336 & 25.600 \\
\hline $\mathrm{S}$ & & 0.465 & 11.391 & 12.942 & 7.290 & 2.625 & 4.225 \\
\hline$X_{\text {ave }}$ & & 9.634 & & & & & \\
\hline Source & $\mathrm{df}$ & SS & MS & $\mathrm{F}$ & P-value & & \\
\hline Treatments & 5 & 536.209 & 107.242 & 1.3276 & 0.2862 & & \\
\hline Error & 24 & 1938.639 & 80.777 & & & & \\
\hline Total & 29 & 2474.848 & & & & & \\
\hline
\end{tabular}

*Values were performed in triplicates and represented as mean \pm SD. 
Table 2. The diameters of the inhibitory zones $(\mathrm{mm})$ of the fungal growth due to watery pumpkin leaves extracts and antifungal drug (Kenazole) in different concentration

\begin{tabular}{|c|c|c|c|c|c|c|}
\hline \multirow[t]{2}{*}{ Fungal species } & \multicolumn{6}{|c|}{ Watery Pumpkin leaves extracts (P.L.E.) and anti-fungal (AF) drug concentrations } \\
\hline & $10 \%$ P. L. E. & $15 \%$ P. L. E. & $25 \%$ P. L. E. & $10 \% \mathrm{AF}$ & $15 \% \mathrm{AF}$ & $25 \% \mathrm{AF}$ \\
\hline Aspergillus fumigatus & $25.00 \pm 0.0$ & $26.00 \pm 1.0$ & $28.33 \pm 0.58$ & $20.67 \pm 1.67$ & $22.00 \pm 1.73$ & $24.33 \pm 1.50$ \\
\hline Aspergillus Niger & $21.33 \pm 1.55$ & $25.00 \pm 0.0$ & $28.33 \pm 1.53$ & $18.67 \pm 1.55$ & $20.66 \pm 1.55$ & $25.00 \pm 1.15$ \\
\hline Candida albicans & 0.00 & $21.66 \pm 1.53$ & $24.67 \pm 0.47$ & $16.00 \pm 1.73$ & $20.00 \pm 0.0$ & $23 . .33 \pm 1.53$ \\
\hline $\mathrm{N}$ & 3 & 3 & 3 & 3 & 3 & 3 \\
\hline $\mathrm{X}$ & 15.443 & 24.220 & 27.110 & 18.447 & 20.887 & 24.110 \\
\hline $\mathrm{S}$ & 13.500 & 2.273 & 2.113 & 2.343 & 1.019 & 1.018 \\
\hline$X_{\text {ave }}$ & 21.703 & & & & & \\
\hline Source & SS & MS & $\mathrm{F}$ & P-value & & \\
\hline Treatments & 275.454 & 55.091 & 1.6574 & 0.2191 & & \\
\hline Error & 398.869 & 33.239 & & & & \\
\hline Total & 674.323 & & & & & \\
\hline
\end{tabular}

Table 3. The diameters of the inhibitory zones $(\mathrm{mm})$ of the bacterial growth due to hexanoic pumpkin leaves extracts and antibiotic (Ciprofloxacin) in different concentrations

\begin{tabular}{|c|c|c|c|c|c|c|}
\hline Type of bacteria & P.L.E.10\% & P.L.E.15\% & P.L.E. $25 \%$ & AB. $10 \%$ & AB. $15 \%$ & AB. $25 \%$ \\
\hline E. coli & $22.33 \pm 2.08$ & $26.33 \pm 1.53$ & $29.67 \pm 1.00$ & $17.67 \pm 2.53$ & $21.67 \pm 1.53$ & $29.33 \pm 1.55$ \\
\hline К.рпеитопіа. & $23.67 \pm 1.53$ & $24.67 \pm 0.58$ & $28.33 \pm 1.53$ & 0.00 & $16.67 \pm 2.31$ & $28.67 \pm 2.31$ \\
\hline Pro.mirabilis & $14.67 \pm 0.58$ & $15.33 \pm 0.58$ & $18.67 \pm 0,58$ & $12.67 \pm 2.82$ & $16.67 \pm 1.53$ & $24.00 \pm 1.00$ \\
\hline Stap.aureus. & $20.00 \pm 0.00$ & $21.00 \pm 1.73$ & $22.33 \pm 1.00$ & $18.00 \pm 1.73$ & $20.67 \pm 1.55$ & $27.00 \pm 1.00$ \\
\hline Ps.aeruginosa & 0.00 & 0.00 & 0.00 & 12,67 & 16.00 & 19.00 \\
\hline $\mathrm{N}$ & 5 & 5 & 5 & 5 & 5 & 5 \\
\hline $\mathrm{X}$ & 16.134 & 17.466 & 19.800 & 12.068 & 18.336 & 25.600 \\
\hline $\mathrm{S}$ & 9.651 & 10.637 & 11.936 & 7.290 & 2.625 & 4.225 \\
\hline$X_{\text {ave }}$ & 18.234 & & & & & \\
\hline Source & Df & SS & MS & $\mathrm{F}$ & P-value & \\
\hline treatments & 5 & 498.700 & 99.740 & 1.4026 & 0.2588 & \\
\hline Error & 24 & 1706.617 & 71.109 & & & \\
\hline Total & 29 & 2205.318 & & & & \\
\hline
\end{tabular}

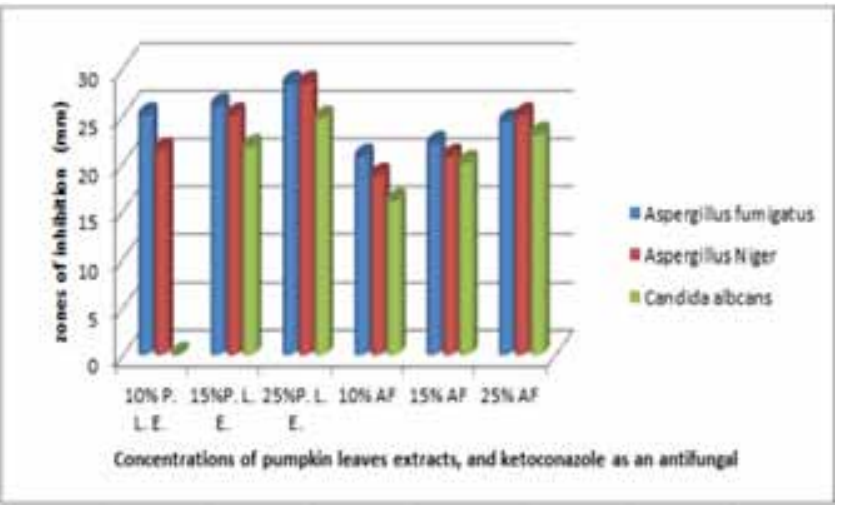

Figure 2. Inhibitory zone of the fungal growth due to watery pumpkin leaves extract (P.L.E.) and anti-fungal drug (AF) in different concentrations.

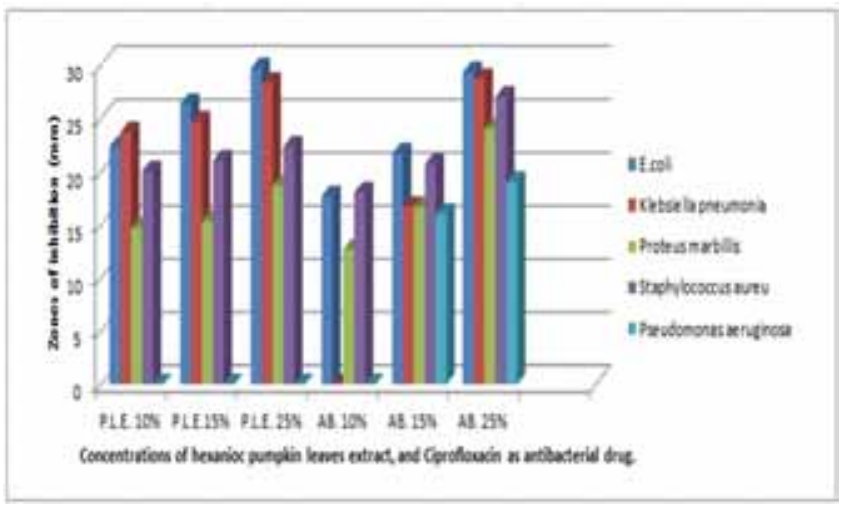

Figure 3. Inhibitory zones of the bacterial growth due to hexanoic pumpkin leaves extract (P.L.E.) and anti-bacterial drug $(\mathrm{AB})$ in different concentrations. 
Table 4. The diameters of the inhibitory zones $(\mathrm{mm})$ of the fungal growth due to hexanoic pumpkin leaves extracts (P.L.E.) and anti-fungal drug (AF) in different concentrations

\begin{tabular}{|c|c|c|c|c|c|c|c|}
\hline Fungal species & \multicolumn{2}{|c|}{$10 \%$ P. L. E. } & 15\%P.L. E. & 25\%P.L. E. & $10 \% \mathrm{AF}$ & $15 \% \mathrm{AF}$ & $25 \% \mathrm{AF}$ \\
\hline Aspergillus fumigatus & \multicolumn{2}{|c|}{$24.33 \pm 1.58$} & $26.33 \pm 1.58$ & $30.33 \pm 1.15$ & $20.67 \pm 1.67$ & $22.00 \pm 1.73$ & $24.33 \pm 1.50$ \\
\hline Aspergillus Niger & \multicolumn{2}{|c|}{0.00} & $22.66 \pm 1.53$ & $31.00 \pm 1.73$ & $18.67 \pm 1.55$ & $20.66 \pm 1.55$ & $25.00 \pm 1.15$ \\
\hline Candida albicans & \multicolumn{2}{|c|}{$20.00 \pm 0.00$} & $27.33 \pm 2.08$ & $31.00 \pm 1.58$ & $16.00 \pm 1.73$ & $20.00 \pm 0.0$ & $23 . .33 \pm 1.53$ \\
\hline $\mathrm{N}$ & \multicolumn{2}{|c|}{3} & 3 & 3 & 3 & 3 & 3 \\
\hline $\mathrm{X}$ & \multicolumn{2}{|c|}{14.777} & 25.773 & 30.777 & 18.447 & 20.887 & 24.110 \\
\hline $\mathrm{S}$ & \multicolumn{2}{|c|}{12.979} & 1.897 & 0.387 & 2.343 & 1.019 & 1.018 \\
\hline$X_{\text {ave }}$ & \multicolumn{2}{|c|}{22.462} & & & & & \\
\hline Source & $\mathrm{df}$ & SS & MS & $\mathrm{F}$ & $\begin{array}{l}\mathrm{P} \text {-value } \\
\end{array}$ & & \\
\hline Treatments & 5 & 481.450 & 96.290 & 3.2139 & 0.0453 & & \\
\hline Error & 12 & 359.527 & 29.961 & & & & \\
\hline Total & 17 & 840.977 & & & & & \\
\hline
\end{tabular}

Table 5. The diameters of the inhibitory zones $(\mathrm{mm})$ of the bacterial growth due to ethanol pumpkin leaves extracts and antibiotic (Ciprofloxacin) in different concentrations

\begin{tabular}{|c|c|c|c|c|c|c|c|}
\hline \multirow{2}{*}{$\begin{array}{l}\text { Types } \\
\text { bacteria }\end{array}$} & \multicolumn{7}{|c|}{ Zones of inhibition (mm) } \\
\hline & P.L.E.10\% & P.L.E.15\% & P.L.E. $25 \%$ & & $10 \%$ & AB. $15 \%$ & AB. $25 \%$ \\
\hline E.coli & $25.33 \pm 0.47$ & $29.00 \pm 1.63$ & $32.00 \pm 2.45$ & & \pm 2.52 & $21.67 \pm 1.53$ & $29.33 \pm 1.55$ \\
\hline K. pneumonia. & $23.33 \pm 1.25$ & $25.67 \pm 1.25$ & $29.67 \pm 0.47$ & & 00 & $16.67 \pm 2.31$ & $28.67 \pm 2.31$ \\
\hline Pro. mirabilis. & $21.33 \pm 0.94$ & $25.00 \pm 0.00$ & $28.67 \pm 1.70$ & & \pm 2.62 & $16.67 \pm 1.53$ & $24.00 \pm 1.00$ \\
\hline Staph. aureus & $24.00 \pm 1.41$ & $25.00 \pm 0.00$ & $28.67 \pm 1.25$ & & \pm 1.73 & $20.67 \pm 1.55$ & $27.00 \pm 1.00$ \\
\hline Ps.aeruginosa & 0.00 & 0.00 & 0.00 & & $67 \pm$ & $16.00 \pm$ & $19.00 \pm$ \\
\hline $\mathrm{N}$ & 5 & 5 & 5 & 5 & 5 & & 5 \\
\hline $\mathrm{X}$ & 18.798 & 20.934 & 23.802 & 12.068 & 18.336 & & 25.600 \\
\hline S & 10.607 & 11.819 & 13.375 & 7.290 & 2.625 & & 4.225 \\
\hline$X_{\text {ave }}$ & 19.923 & & & & & & \\
\hline Source & $\mathrm{df}$ & SS & MS & $\mathrm{F}$ & P-value & & \\
\hline Treatments & 5 & 568.912 & 113.782 & 1.3413 & 0.2810 & & \\
\hline Error & 24 & 2035.964 & 84.832 & & & & \\
\hline Total & 29 & 2604.876 & & & & & \\
\hline
\end{tabular}

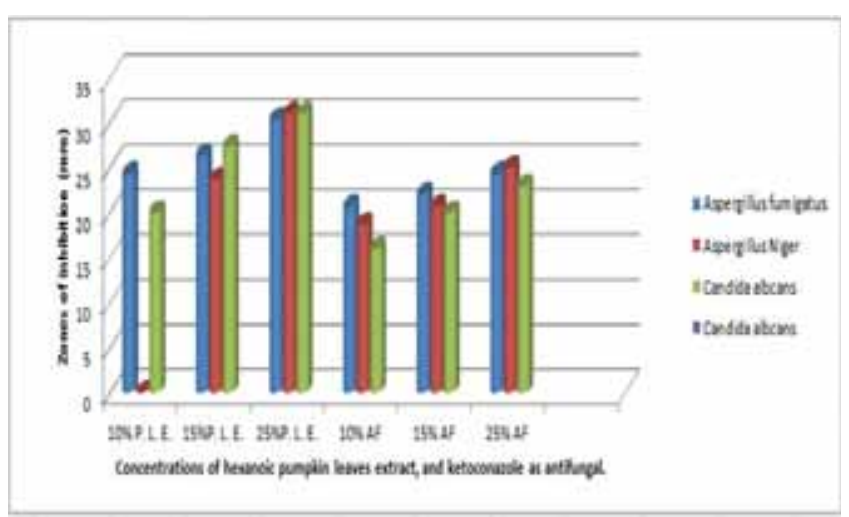

Figure 4. Inhibitory zone of the fungal growth due to hexanoic pumpkin leaves extract (P.L.E.) and anti-fungal drug (AF) in different concentrations.

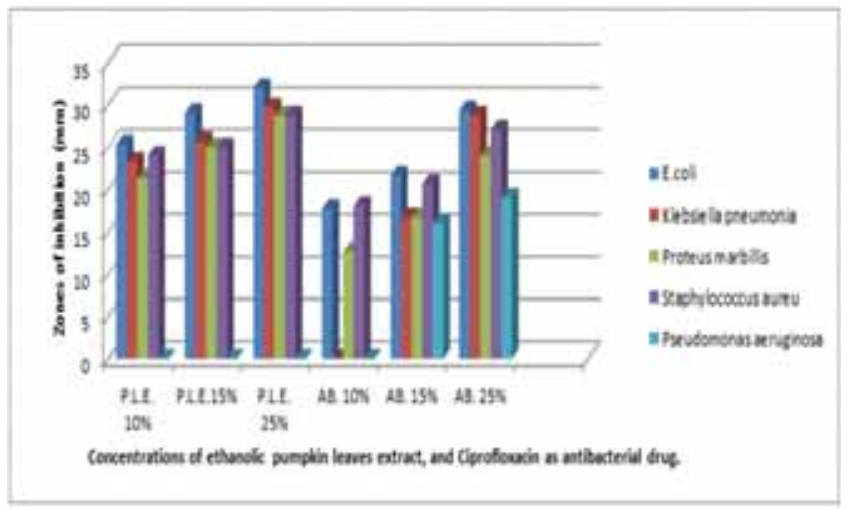

Figure 5. The Inhibitory zones of the bacterial growth due to ethanol pumpkin leaves extracts (P.L.E.) and antibacterial drug $(\mathrm{AB})$ in different concentrations. 
Table 6. The diameters of the inhibitory zones $(\mathrm{mm})$ of the fungal growth due to ethanol pumpkin leaves extracts (P.L.E.) and anti-fungal drug (AF) in different concentrations

\begin{tabular}{|c|c|c|c|c|c|c|}
\hline Type of fungal species & $10 \%$ P. L. E. & $15 \%$ P. L. E. & 25\%P. L. E. & $10 \% \mathrm{AF}$ & $15 \% \mathrm{AF}$ & $25 \% \mathrm{AF}$ \\
\hline Aspergillus fumigatus & 25.33 & 27.67 & 30.67 & $20.67 \pm 1.67$ & $22.00 \pm 1.73$ & $24.33 \pm 1.50$ \\
\hline Aspergillus Niger & 21.33 & 25.00 & 28.33 & $18.67 \pm 1.55$ & $20.66 \pm 1.55$ & $25.00 \pm 1.15$ \\
\hline Candida albicans & 25.00 & 26.33 & 28.67 & $16.00 \pm 1.73$ & $20.00 \pm 0.0$ & $23 . .33 \pm 1.53$ \\
\hline $\mathrm{N}$ & 3 & 3 & 3 & 3 & 3 & 3 \\
\hline $\mathrm{X}$ & 23.887 & 26.333 & 29.223 & 18.447 & 20.887 & 24.110 \\
\hline $\mathrm{S}$ & 2.220 & 1.335 & 1.264 & 2.343 & 1.019 & 1.018 \\
\hline$X_{\text {ave }}$ & 23.814 & & & & & \\
\hline Source & SS & MS & $\mathrm{F}$ & P-value & & \\
\hline Treatments & 219.235 & 43.847 & 16.5722 & 0.0001 & & \\
\hline Error & 31.750 & 2.646 & & & & \\
\hline Total & 250.985 & & & & & \\
\hline
\end{tabular}

Table 7. Zones of inhibition of different bacteria species with different concentrations of the extracts

\begin{tabular}{|c|c|c|c|c|c|c|c|}
\hline \multirow{2}{*}{\multicolumn{3}{|c|}{ Bacteria species $+\%$ Extract }} & \multicolumn{5}{|c|}{ Types solvents } \\
\hline & & & \multirow{2}{*}{\multicolumn{2}{|c|}{ Water }} & \multirow{2}{*}{$\frac{\text { Hexane }}{22.33}$} & \multirow{2}{*}{$\frac{\text { Ethanol }}{25.33}$} & \multirow{2}{*}{$\begin{array}{c}\text { Pet. Ether } \\
0.00\end{array}$} \\
\hline \multicolumn{3}{|c|}{ E. coli $+10 \%$ Extract } & & & & & \\
\hline \multicolumn{3}{|c|}{ E.coli $+15 \%$ Extract } & & & 26.33 & 29.33 & 0.00 \\
\hline \multicolumn{3}{|c|}{ E. coli $+25 \%$ Extract } & & & 31 & 32 & 0.00 \\
\hline \multicolumn{3}{|c|}{ K. pneumonia $+10 \%$ Extract } & & & 23.66 & 23.33 & 0.00 \\
\hline \multicolumn{3}{|c|}{ К.pneumonia $+15 \%$ Extract } & & & 24.66 & 25.67 & 0.00 \\
\hline \multicolumn{3}{|c|}{ K. Pneumonia $+25 \%$ Extract } & & & 28.33 & 29.67 & 0.00 \\
\hline \multicolumn{3}{|c|}{ Proteus mirabilis $+10 \%$ Extract } & & & 15.33 & 22.67 & 0.00 \\
\hline \multicolumn{3}{|c|}{ Proteus mirabilis $+15 \%$ Extract } & & & 16.00 & 26.33 & 0.00 \\
\hline \multicolumn{3}{|c|}{ Proteus mirabilis $+25 \%$ Extract } & & & 19.67 & 29.33 & 0.00 \\
\hline \multicolumn{3}{|c|}{ Staphylococcus aureus $+10 \%$ Extract } & & & 20.00 & 23.33 & 0.00 \\
\hline \multicolumn{3}{|c|}{ Staphylococcusaureus+15\% Extract } & & & 21.00 & 28.33 & 0.00 \\
\hline \multicolumn{3}{|c|}{ Staphylococcus aureus $+25 \%$ Extract } & & & 23.00 & 30.00 & 0.00 \\
\hline \multicolumn{3}{|l|}{$\mathrm{N}$} & & & 12 & 12 & 12 \\
\hline \multicolumn{3}{|l|}{$\mathrm{X}$} & & & 22.609 & 27.110 & 0.000 \\
\hline \multicolumn{3}{|l|}{$\mathrm{S}$} & & & 4.644 & 3.079 & 0.000 \\
\hline$X_{\text {ave }}$ & & & & & & & \\
\hline Source & Df & SS & MS & $\mathrm{F}$ & & & \\
\hline Treatments & 3 & 5809.507 & 1936.502 & 192.7469 & & & \\
\hline Error & 44 & 442.062 & 10.047 & & & & \\
\hline Total & 47 & 6251.569 & & & & & \\
\hline
\end{tabular}

\section{Discussion}

The results obtained from the present investigation revealed that water seems to be the best solvent for pumpkin leaves compounds as it is highly polar solution than other organic solvents.

Reported that water extract of some plants showed strongest anti- fungal activities against photo pathogenic fungi $(15,16)$.

Ethanol and hexane are able to dissolve non-lipids organic compounds with lipids, whereas petroleum ether extract shows no antibacterial activities and showed moderate activity against the fungal species. These results were in agreement with (16) which may be due to the ability of petroleum ether to dissolve only lipids whereas other organic solvents have the ability to dissolve other compounds such as carbohydrate and other phytochemical compounds.

These results were in agreement with previous results obtained by watery and ethanolic extracts (17) who demonstrate the presence of saponin, alkaloid and tannins and phenol in the extract of the pumpkin leaves which synergistically proved as an antimicrobial (14). Saponin 
exhibited both hemolytic and antibacterial activities against Staphylococcus aureus, Salmonella Typhimurium and Escherichia coli $(19,20)$. Tannins also had antibacterial, and anti-fungal activities $(9,21)$. These compounds which synergistically proved antimicrobial which had antimicrobial activity against bacteria and fungi (18).

Although there were no significant differences among different solvents, ethanolic and hexanolic extracts seem to have better activity against $E$. Coli, Klebsiella pneumonia, Proteus marbillis and Staphylococcus aureus. On the contrary our results show no effect on Pseudomonas aeruginosa.

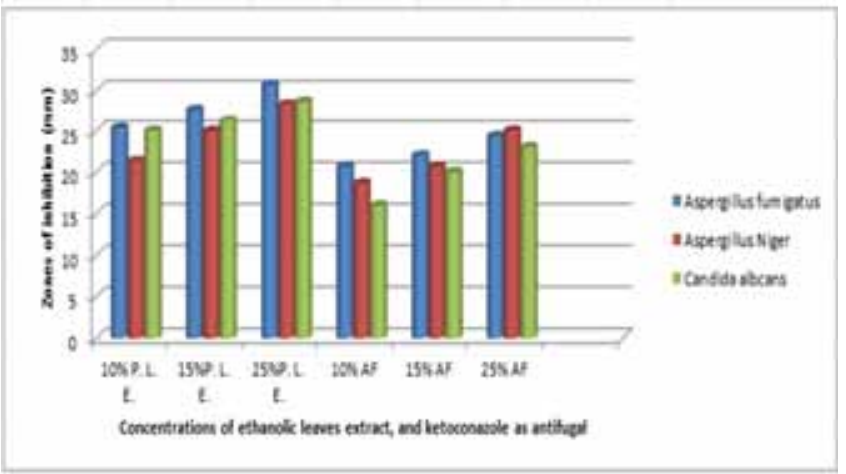

Figure 6. The inhibitory zone of the fungal growth due to ethanolic pumpkin leaves extract (P.L.E.) and anti-fungal drug $(\mathrm{AF})$ in different concentrations.

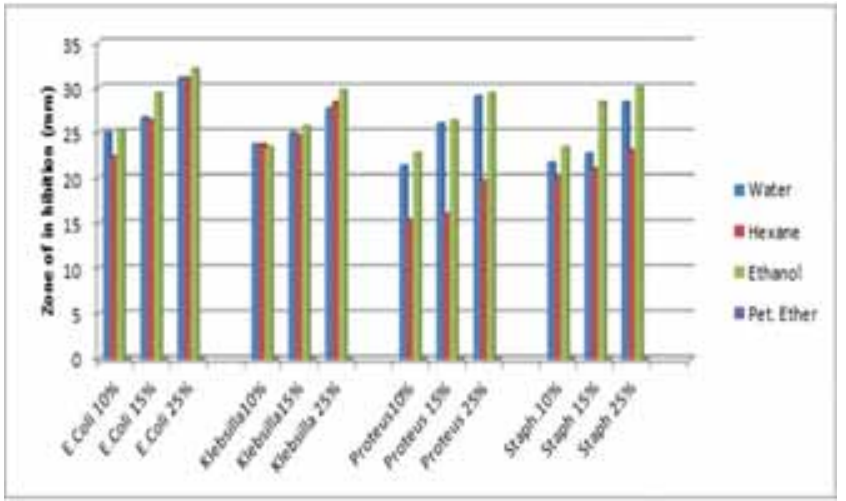

Figure 7. Antibacterial activities of different solvents extract against bacteria species with different extract concentrations.

\section{Conclusions}

The results obtained from the present investigation revealed that water seems to be the best solvent for pumpkin leaves compounds as it is highly polar solution than other organic solvents.

\section{References}

1. Ebrahim A, Maral M,.Hamid R,. Bozorgia A. Sudy medical plant in holy Quran, Inter J plant, Ani Environ Sci. 2014;4(2):529-536.

2. Baliarsingh S, Panda AK, Jena J, Das T and Das NB. Exploring sustainable technique onnatural dye extraction from native plants for textile: identification of colourants, colourimetric analysis of dyed yarns and their antimicrobial evaluation. $\mathrm{J}$ Cleaner Produ. 2012;37:257-264.

3. Doss A, Mohammed H, and Dhanabalan R. Antibacterial activity of tannins from the leaves of Solanum trilobatum Linn. Indian J Sci Technol. 2009); 2(2):41-43

4. Belguith $\mathrm{H}$, and Kthiri F. Inhibitory effect of aqueous extract of Allium Sativum. Afr J Microbiol Res. 2010; 4(5):328-338.

5. Lin ZS, Anjaneya S, Ravipatia R, Koyyalamudia S, Chul J, Narsimha etal., Anti-fungal and anti-bacterial activities of ethanol extracts of selected traditional Chinese medicinal herbs. Asian Pac J Trop Med. 2013;673-681

6. Kumudini I, Shubha T, Deepak G, Shirish K, an Kumar dA.Antimicrobial activity of Sphagneticola trilobata (L.) Pruski, Aganist some human pathogenic bacteria and fungi. Bioscan. 2013;8(2):695-700.

7. El-Sinary NH, Evaluation of the Insecticidal Effect of Pumpkin Cucurbita pepo Against Potato Tubermoth Phthorimaea operculella (Zeller) Combined with Gamma Irradiation. Amer Euras J Sci Res. 2006;1(1):18-22.

8. Akhilesh D, Mishra N, Singh N. Antimicrobial activity of some selected vegetables. Intern J Appl Biol Pharmace Technol. 2010;1(3):994-999.

9. Scalbert A. Antimicrobial properties of Tannins. Phytochem. 1991;30 (12):3873-3883.

10. Hassana SM, Haqb AU, Byrdc JA, Berhowd MA, artwrightb AL, Baileyb CA. Haemolytic and antimicrobial activities of saponin-rich extracts from guar meal. Food Chem. 2010;119(2):600-605.

11. NCCLS Manual of Antimicrobial Susceptibility Testing. Research Gate, 2005.

12. Cowan and Steel's ST. manual for identification of medical bacteria. $2^{\text {nd }}$ edition. Cambridge University press, Cambridge, London. 1985;pp:138-139.

13. Tariq K, Muhammad M, Khan S, Inamullah Z, Mustafa I, etal., Antimicrobial and Phytochemical activities of Micromeria biflora. Inter J Microbiol. 2015;1(1):1-5.

14. Southwestern Adventist University. ANOVA statistical analysis on line. 2016.

15. Ramalingam R, Krishnan T,. Venkatesan K, Khanna G, Antibacterial activity of saponin isolated from the leaves of Solanum trilobatum Linn. J Pharm Res. 2009;2 2:273-278.

16. Raji R, and Raveendran K. Antifungal activity of selected plant extracts against phytopathogenic fungi Aspergillus niger. Asian $\mathrm{J}$ Plant Sci Res. 2013;3(1):13-15.

17. Jadhav VD, Bhanuwanshe SM, Patil S P, Chaudhari DV, Adke MB. Antibacterial Activity Of Different Plant And Callus Extracts A Comparative Study. Intern J Sci Technol Res. 2013;2(10):285-288

18. Olorunfemi A, Sattar A, Hassaan A. Review of the Pharmacological and Biological Activities of the Aerial Parts of Telfairia occidentalis Hook.f. (Cucurbitaceae). 2014

19. Ganiyu O, and Christianah A. Antioxidant and Antimicrobial Properties of Telfaira occidentalis (Fluted pumpkin) Leaf Extracts. J Pharmacol Toxicol. 2006;167:175.

20. Pinarosa A, Bucci R, Tava A, Vitali C, Rosato A, Antimicrobial Activity of Saponins from Medicago sp.: Structure-Activity Relationship. Phytother Res. 2006;20:454-457.

21. Alani SA, Glazada F, Tarres JA, Ceballas J. Antibacterial properties of some plants used in Mexican traditional medicine for the treatment of gastro intestine disorders. J Ethnopharmacol. 2005;153-157. 